\title{
PENGARUH RISIKO PASAR DAN TINGKAT KECUKUPAN MODAL TERHADAP PROFITABILITAS PADA BANK BNI PERIODE 2013 - 2020
}

\author{
Lidia Noer Khoeriah \\ e-mail: lidiankk@gmail.com \\ Gusganda Suria Manda \\ e-mail: gusganda.suriamanda@fe.unsika.ac.id
}

(Program Studi Akuntansi, Fakultas Ekonomi, Universitas Singaperbangsa, Karawang)

\begin{abstract}
ABSTRAK : Dalam industri perbankan, perusahaan selalu berusaha menghindari risiko baik di dalam maupun di luar organisasi atau badan usaha. Tujuan dari penelitian ini adalah untuk mengetahui apakah risiko pasar bank (NIM) dan rasio kecukupan modal (CAR) BNI dari tahun 2013 hingga 2020 berpengaruh secara simultan atau parsial terhadap profitabilitas (ROA). Penelitian ini merupakan jenis penelitian kuantitatif. Populasi dalam penelitian ini adalah seluruh laporan keuangan triwulanan Bank BNI tahun 2013 sampai tahun 2020. Hingga 30 sampel penelitian diperoleh. Teknik analisis yang digunakan dalam penelitian ini adalah analisis regresi linier berganda dengan bantuan program IBM SPSS Statistics 25. Hasil penelitian menunjukkan bahwa: (1) Secara simultan risiko pasar (NIM) dan tingkat kecukupan modal (CAR) berpengaruh signifikan terhadap profitabilitas (ROA), (2) Secara parsial hasil penelitian pada variabel risiko Pasar (NIM) berpengaruh signifikan dan mempunyai hubungan positif terhadap profitabilitas (ROA), (3) Secara parsial hasil penelitian pada variabel tingkat kecukupan modal (CAR) berpengaruh signifikan dan mempunyai hubungan positif terhadap profitabilitas (ROA).
\end{abstract}

Kata Kunci : Net Interets Margin, Capital Adequacy Ratio, Return on Asset

ABSTRACT : In the banking industry, every company always try to avoid risk, both inside and outside of the organization business entity. The purpose of this study was to determine whether the bank's market risk (NIM) and capital adequacy ratio (CAR) BNI from 2013 to 2020 had a simultaneous or partial effect on profitability (ROA). The type of this study is quantitative study. The population in this study is BNI's quarterly financial reports from 2013 to 2020. Up to 30 study samples were obtained. The analysis technique used in this study is multiple linear regression analysis with the help of the IBM SPSS Statistics 25 program. The results showed that: (1) Simultaneously, market risk (NIM) and the level of capital adequacy ratio (CAR) have a significant effect on profitability (ROA), (2) Partially, the results on the market risk variable (NIM) have a significant effect and have a positive relationship on profitability (ROA), (3) Partially, the results on the variable level of capital adequacy ratio (CAR) have a significant effect and have a positive relationship to profitability (ROA).

Keywords : Net Interest Margin, Capital Adequacy Ratio, Return on Asset 


\section{PENDAHULUAN}

Dewasa ini, negara-negara di seluruh dunia sedang berlomba-lomba dalam melakukan pembangunan kembali negaranya, hal ini disebabkan oleh pandemi virus pada bulan maret 2020 yang dikenal sebagai corona virus. Pandemi tersebut sangat berdampak negatif pada setiap sektorsektor pembangunan negara, khususnya faktor ekonomi. Salah satu indikator utama dalam memperbaiki taraf hidup masyarakat adalah pembangunan ekonomi suatu negara. Sistem keuangan yang sehat dan stabil menjadi salah satu indikator utama dalam pembangunan suata negara. Ketersediaan dan peran serta lembaga keuangan dibutuhkan demi perkembangan perekonomian ini. Salah satu contoh lembaga keuangan dalam suatu negara adalah perbankan. Perbankan merupakan instansi yang turut ikut serta dalam kegiatan pembangunan ekonomi suatu negara dan juga secara tidak langsung merefleksikan bagaimana kondisi taraf hidup masyarakat dalam suatu negara tersebut. Profitabilitas, atau yang diketahui juga sebagai kemampuan suatu perusahaan untuk mendapatkan laba merupakan salah satu indikator penilaian yang dapat dihitung. Terdapat banyak faktor yang dapat mempengaruhi besar kecilnya nilai profitabilitas suatu perusahaan.

Tak hanya profitabilitas, terdapat juga faktor-faktor lain yang dapat merefleksikan perkembangan suatu negara, Risiko pasar merupakan salah satunya. Risiko pasar merupakan faktor yang tidak dapat dihindari perusahaan, hal ini dikarenakan kondisi dan situasi pasar yang diluar kendali perusahaan. Pada industri perbankan, hubungan suku bunga terdapat dua macam yaitu suku bunga pinjaman dan simpanan. Pada industri perbankan, permodalan pun merupakan salah satu faktor yang penting, bank diharuskan kuat menjaga tingkat kepercayaan dari nasabah dengan cara mempunyai modal yang cukup untuk operasional perusahaan sehari-hari.

\section{Tujuan Penelitian}

1. Guna mengetahui \& menganalisis pengaruh risiko pasar terhadap profitabilitas Bank BNI

2. Guna mengetahui \& menganalisis pengaruh tingkat kecukupan modal terhadap profitabilitas Bank BNI periode 2013 hingga 2020

3. Guna mengetahui dan menganalisis secara simultan pengaruh risiko pasar dan tingkat kecukupan modal terhadap profitabilitas Bank BNI

\section{TINJAUAN PUSTAKA}

Bank

Menurut kasmir, secara sederhana bank memiliki kegiatan utama yaitu sebagai lembaga keuangan yang menghimpun serta menyalurkan dana tersebut kembali ke nasahabh (masyarakat) dan menyediakan layanan perbankan lainnya. Dari sudut pandang asal bank, bank berasal dari bahasa Italia yaitu kata bancu yang artinya meja atau tempat untuk menukar mata uang. Bankir menggunakan formulir ini untuk memberikan layanan kepada pelanggan. Istilah bancu kemudian resmi menjadi bank. Bank dapat dengan mudah digambarkan sebagai pusat keuangan yang usahanya mengumpulkan uang dari masyarakat untuk dikembalikan kepada publik untuk menyediakan layanan perbankan lainnya.(Kasmir, 2014)

\section{Profitabilitas}

Profitabilitas bank adalah profitabilitas bank. Profitabilitas atau pendapatan bank merupakan hal yang penting, karena pendapatan bank merupakan tujuan utama yang harus didirikan, karena bank didirikan untuk mencari keuntungan. Keuntungan yang diperoleh dari aktivitas pendanaan berupa selisih biaya modal dengan pendapatan bunga yang diterima dari debitur. Keuntungan 
adalah tujuan utama bank, jadi perhatian harus diberikan. Sebagai ukuran kemampuan perusahaan memperoleh keuntungan dari aktivitas yang digunakannya yaitu disebut Return on assets (ROA). Return on asset dapat dihitung dari laba sebelum pajak dan bunga, dibandingkan dengan total keseluhurann aset yang dimiliki perusahaan. Tingkat pengembalian aset (ROA) yang positif dapat menunjukkan bahwa perusahaan tersebut dapat memberikan keuntungan bagi perusahaan dari total aset yang digunakan untuk operasi. Sebaliknya jika return on negative equity merepresentasikan jumlah total aset yang digunakan perusahaan, maka perusahaan tersebut akan mengalami kerugian.

Dimana ukuran laba dapat dihitung menggunakan rumus sebagai berikut :

$$
\text { ROA }=\frac{\text { Laba sebelum pajak }}{\text { Total Aktiva }(\text { Rata-Rata })} \times 100 \%
$$

\section{Risiko Pasar}

Menurut Hanafi Risiko pasar didefinisikan sebagai risiko kehilangan posisi neraca karena perubahan harga pasar dan pencatatan klaim dan kewajiban off-balance sheet (on-balance sheet dan off-balance sheet). Risiko pasar dapat dilihat pada kegiatan fungsional bank itu sendiri seperti treasury (tradding book). Risiko pasar yang terjaadi paada bank dikarenakan bank memiliki posisi, baik posisi tradding book maupun posisi banking book, ditambah dengan adanya faktor pasar yang berubah-ubah dapat berdampak pada nilai pasar dari posisi pasar berubah (Hanafi, 2012)

Risiko pasar mengacu pada risiko perubahan harga pasar dari portofolio investasi dan posisi off-balance sheet (termasuk transaksi derivatif). Perubahan harga dapat terjadi dikarenakan adanya perubahan dari faktor pasar, termasuk risiko perubahan harga opsi. Faktor pasar yang disebut adalah nilai tukar, tingkat bunga atau tingkat distribusi keuntungan, harga saham dan harga komoditas. Pengukuran risiko pasar suatu bank dapat dihitung menggunakan rasio Net Interest Margin (NIM) dengan rumus :

$$
\text { Net Interest Margin }=\frac{\text { Pendapatan Operasional }}{\text { Rata }- \text { rata Aktiva Produktif }} \times 100 \%
$$

\section{Tingkat Kecukupan Modal}

Menurut Aakesa (2006), rasio kecukupan modal merupakan persyaratan modal yang merupakan rasio terkecil antara modal berisiko dan aset yang menanggung risiko. Semakin tinggi rasio kecukupan modal yang didapat oleh bank, hal tersebut dapat menandakan bahwa kinerja bank semakin membaik, dan laba bank akan bertambah meningkat.(Aakesa, 2006)

CAR (Capital Adequacy Ratio) adalah persyaratan modal dan merupakan rasio terkecil antara modal berisiko dan aset yang mengandung risiko. Menurut Jumingan (2006), rumus dasar perhitungan CAR matematis adalah sebagai berikut: (Jumingan, 2006)

$$
\mathrm{CAR}=\frac{\text { Modal }}{\text { ATMR }} \times 100 \%
$$

\section{Hubungan Risiko Pasar dengan Profitabilitas}

Akibat perubahan kondisi pasar, Suku bunga bersih (NIM) mencerminkan risiko pasar yang dapat merugikan bank. (Hasibuan, 2007)

Net interest margin (NIM) digunakan untuk mengukur kemampuan manajemen bank didalam menghasilkan pendapatan dari bunga dengan dilihat dari kinerja bank tersebut dalam memandu pembiayaan, mengingat pendapatan operasional bank sangat bergantung pada 
selisih bunga dalam pembiayaan yang dialokasikan. (Mahardian, 2003). Net interest margin (NIM) merupakan rasio yang dapat menunjukkan kemampuan sebuah manajemen perbankan tersebut dalam mengelola aset yang menguntungkan guna menghasilkan pendapatan bunga bersih. Pendapatan bunga bersih diperoleh melalui pembiayaan, dan bank harus membayar bunga kepada deposan. Semakin besar rasionya, semakin tinggi pendapatan bunga dari aset produktif yang dikelola oleh pihak bank sehingga dapat mengurangi kemungkinan bank bermasalah. Dengan demikian dapat disimpulkan bahwa semakin besar perubahan tingkat bunga bersih (NIM) bank maka profitabilitasnya semakin besar, yang artinya kinerja keuangan akan semakin baik.

Ha1 : NIM memiliki pengaruh positif terhadap Profitabilitas Bank BNI.

\section{Hubungan Tingkat Kecukupan Modal dengan Profibilitas}

Menurut (Dendawijaya, 2009), Dampak dari Capital Adequacy Ratio terhadap profitabilitas (Return On Asset) dapat diungkapkan sebagai berikut: Tingkat kecukupan modal digunakan sebagai indikator untuk mengukur kesehatan bank. Sehingga dapat diartikan sebagai kemampuan dari bank untuk menjalankan bisnis perbankan secara normal, sehat dan menjalankan seluruh kewajibannya sesuai dengan ketentuan perbankan yang telah berlaku. Untung merupakan salah satu tanda keberhasilan suatu badan usaha atau perusahaan. Informasi tentang kinerja perusahaan sangat dibutuhkan, terutama informasi tentang profitabilitas perusahaan (profitabilitas), rasio tersebut dapat dipergunakan dalam menilai potensi tiap-tiap perubahan sumber daya ekonomi yang dapat dikendalikan di periode selanjutnya ataupun di masa depan. Dalam penilaian rasio, pihak manajemen bank lebih menitik beratkan perhatiannya terhadap penilaian besarnya ROA, karena manajemen bank lebih mengutamakan nilai profitabilitas pada bank tersebut, nilai profitabilitas aset terutama yang berasal dari simpanan nasabah (masyarakat). Capital Adequacy Ratio merupakan salah satu faktor penting dalam pengembangan bisnis bank dan kerangka pemulihan kerugian yang dapat mencerminkan kesehatan bank tersebut, yang bertujuan untuk menjaga kepercayaan masyarakat terhadap bank, melindungi dana masyarakat dari bank dan memenuhi standar BIS. Dengan dana yang kuat masyarakat dapat menjaga kepercayaan masyarakat terhadap bank yang bersangkutan, sehingga masyarakat yakin bahwa dana yang terkumpul di bank tersebut, kemudian dana yang terkumpul akan mengalir kembali ke masyarakat dari pihak bank sebagai kreditur dalam bentuk kredit. Dalam bentuk kredit, dapat mendorong pendapatan untuk menghasilkan bunga, dan bank dapat memperoleh keuntungan darinya. Melalui tingkat keuntungan atau profitabilitas tersebut, pihak bank dapat memperbaiki struktur permodalan yang lebih efisien dan lebih kuat sehingga membentuk posisi keuangan yang sehat.

$\mathrm{Ha}_{2}$ : Capital Adequacy Ratio (CAR) memiliki pengaruh positif terhadap Profitabilitas (ROA) pada Bank BNI.

\section{Peneliti terhulu}

1. Penelitian yang dilakukan oleh Harsanti (2016) terlihat bahwa patient risk tidak berpengaruh signifikan terhadap pertumbuhan margin keuntungan yang paling umum terjadi di Indonesia. (Harsanti, 2016)

2. Penelitian yang dilakukan oleh Nurfakhri Anugrah Ramadhan (2018) terlihat bahwa risiko pasar berpengaruh positif secara signifikan terhadap profitabilitas .Oleh karena itu, hipotesis terakhir diterima secara parsial. Hal ini menunjukkan bahwa ketika risiko pasar meningkat, pasar akan cenderung mengalihkan asetnya ke perbankan sehingga dianggap lebih aman. (Ramadhan, 2018) 
3. Penelitian Anggraini (2011) Terlihat bahwa rasio kecukupan modal berpengaruh terhadap margin keuntungan, sehingga jika semakin tinggi rasio kecukupan modal yang diperoleh bank maka semakin baik kinerja bank dan pendapatan laba bank akan meningkat. (Ayunigrum, 2011)

4. Penelitian yang dilakukan oleh Fifit Syaiful Putri (2013) terlihat bahwa tingkat kecukupan modal yang dihitung dan diukur dengan rasio kecukupan modal (CAR) berpengaruh positif dengan tingkat yang signifikan terhadap profitabilitas perusahaan perbankan yang terdaftar pada Bursa Efek Indonesia. (IDX). Dari 2006 hingga 2010.(Putri, 2013)

\section{Kerangka pemikiran}

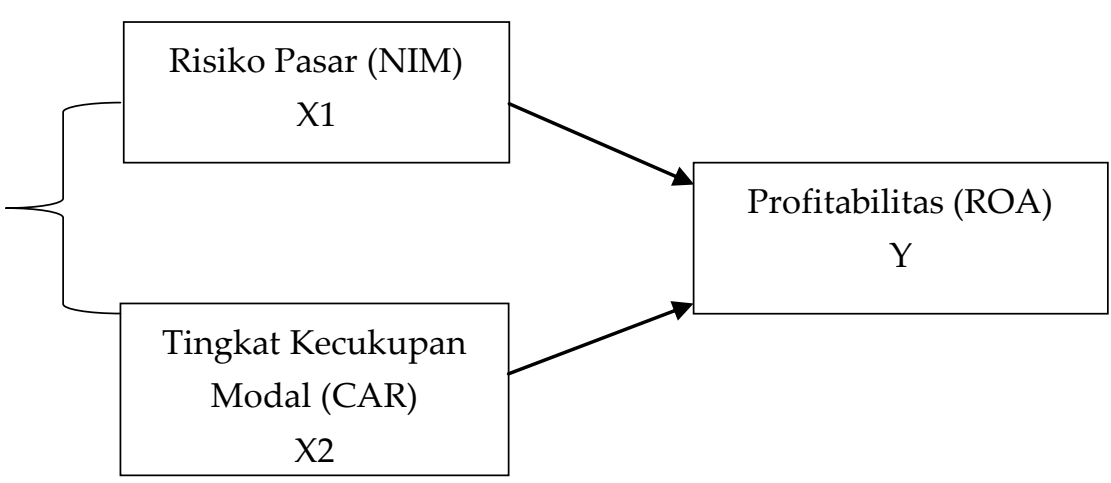

Gambar 1. Kerangka Konseptual

Sumber : Penulis,2021

\section{METODE}

Jenis penelitian yang dipakai pada penelitian ini yaitu penelitian kuantitatif dengan menekankan pda pengujian teori-teori melalui penghitungan variabel-variabel pada penelitian dengan angka serta dilakukannya analisis data dengan prosedur statistik. Populasi yang diidentifikasi dalam penelitian ini adalah perusahaan perbankan. Sampel yang digunakan pada penelitian ini adalah Bank Nasional Indonesia (BNI) dengan periode penelitian tahun 2012 hingga 2020 sebanyak 30 data laporan keuangan triwulan. Peneliti menggunakan dengan metode kuantitatif yang telah diolah dalam laporan keuangan triwulanan PT. Data dari Bank Nasional Indonesia (BNI) dari tahun 2012 hingga 2020. Model yang digunakan untuk menganalisis data terhadap penelitian ini yaitu dengan menggunakan analisis regresi linier berganda. Segala bentuk analisis yang termasuk dalam penelitian menunjukkan cara berpikir. Pernyataan ini terkait dengan evaluasi sistem dan sebagian menentukan relevansi. Software komputer SPSS mendukung data yang diperlukan untuk kepentingan pada penelitian ini . 


\section{PEMBAHASAN}

Tabel 1. Hasil Uji Regresi Linear Berganda

\section{Coefficients $^{a}$}

\begin{tabular}{|c|c|c|c|c|c|c|c|c|}
\hline \multirow{2}{*}{\multicolumn{2}{|c|}{ Model }} & \multicolumn{2}{|c|}{ Unstandardized Coefficients } & \multirow{2}{*}{$\begin{array}{l}\text { Standardized } \\
\text { Coefficients } \\
\text { Beta }\end{array}$} & \multirow[b]{2}{*}{$\mathrm{t}$} & \multirow[b]{2}{*}{ Sig. } & \multicolumn{2}{|c|}{ Collinearity Statistics } \\
\hline & & $\mathrm{B}$ & Std. Error & & & & Tolerance & VIF \\
\hline \multirow[t]{3}{*}{1} & (Constant) & 2.807 & 1.570 & & 1.788 & .085 & & \\
\hline & NIM & .300 & .153 & .340 & 1.961 & .060 & .952 & 1.050 \\
\hline & CAR & -.098 & .063 & -.270 & -1.561 & .130 & .952 & 1.050 \\
\hline
\end{tabular}

a. Dependent Variable: ROA

Sumber: Data diolah oleh penulis dengan menggunakan SPSS versi 25

Berdasarkan hasil di atas. diperoleh nilai a sebesar 2.807, nilai b1 sebesar 0.300 dan b2 sebesar -0.098. Persamaan regresi linear berganda sebagai berikut: $\mathrm{Y}=2.807+0.300 \mathrm{X} 1+-0.098 \mathrm{X} 2$. Persamaan regresi menjelaskan bahwa nilai (constant) menunjukkan nilai sebesar 2.807. Artinya, jika nilai variabel independet (bebas) CAR (X1) dan NIM (X2) nilainya 0, maka nilai variabel dependent (terikat) ROA 2.807. Dengan demikian dapat diketahui bahwa ada atau tidaknya CAR dan NIM terhadap ROA memiliki nilai yang baik.

Tabel 2. Hasil Uji Secara pasrsial Uji (t) NIM terhadap ROA

\section{Coefficients $^{\mathrm{a}}$}

\begin{tabular}{|c|c|c|c|c|c|c|}
\hline \multirow{2}{*}{\multicolumn{2}{|c|}{ Model }} & \multicolumn{2}{|c|}{ Unstandardized Coefficients } & \multirow{2}{*}{$\begin{array}{c}\text { Standardized } \\
\text { Coefficients } \\
\text { Beta } \\
\end{array}$} & \multirow[b]{2}{*}{$\mathrm{t}$} & \multirow[b]{2}{*}{ Sig. } \\
\hline & & B & Std. Error & & & \\
\hline \multirow[t]{2}{*}{1} & (Constant) & .757 & .882 & & .858 & .398 \\
\hline & NIM & .352 & 153 & .399 & 2.300 & .029 \\
\hline
\end{tabular}

a. Dependent Variable: ROA

Sumber: Data diolah oleh penulis dengan menggunakan SPSS versi 25

Pengaruh NIM terhadap ROA sebesar $0.029<0.5$. Sehingga peneliti dapat menyimpulkan bahwa Ha diterima dan $\mathrm{H} 0$ ditolak yang berarti dapat diartikan adanya pengaruh signifikan antara NIM terhadap ROA. 
Tabel 3. Hasil Uji Secara pasrsial Uji (t) CAR terhadap ROA

\section{Coefficientsa}

\begin{tabular}{|c|c|c|c|c|c|c|}
\hline \multirow[b]{2}{*}{ Model } & & \multicolumn{2}{|c|}{ Unstandardized Coefficients } & \multirow{2}{*}{$\begin{array}{c}\text { Standardized } \\
\text { Coefficients } \\
\text { Beta }\end{array}$} & \multirow[b]{2}{*}{$\mathrm{t}$} & \multirow[b]{2}{*}{ Sig. } \\
\hline & & $\mathrm{B}$ & Std. Error & & & \\
\hline 1 & (Constant) & 5.007 & 1.152 & & 4.346 & .000 \\
\hline & CAR & -.125 & .064 & -.345 & -1.942 & .062 \\
\hline
\end{tabular}

a. Dependent Variable: ROA

Sumber: Data diolah oleh penulis dengan menggunakan SPSS versi 25

Pengaruh CAR terhadap ROA sebesar $0.062<0.5$. Berdasarkan dari hasil tersebut, peneliti dapat menyimpulkan bahwa Ha diterima dan H0 ditolak yang berarti dapat diartikan adanya pengaruh secara signifikan antara CAR terhadap ROA.

\section{Tabel 3. Koefisien Determinasi}

\begin{tabular}{ll|l|l|l|l} 
& & \multicolumn{2}{c}{ Model Summary } \\
Model & $\mathrm{R}$ & R Square & $\begin{array}{l}\text { Adjusted } \\
\text { Square }\end{array}$ & $\mathrm{R}$ & $\begin{array}{l}\text { Std. Error of } \\
\text { the Estimate }\end{array}$ \\
\hline 1 & $.478^{\mathrm{a}}$ & .229 & .171 & .47106 \\
\hline
\end{tabular}

a. Predictors: (Constant), CAR, NIM

Sumber: Data diolah oleh penulis dengan menggunakan SPSS versi 25

Berdasarkan hasil pada Tabel yang menunjukkan koefisien determinasi (R2) sebesar 0.478 yang berarti $47.8 \%$ Risiko pasar dapat dijelaskan oleh Tingkat kecukupan modal dan profitabilitas. Sedangkan sisanya sebesar 52.2\% dijelaskan oleh factor-faktor lain diluar metode penelitian ini.

Tabel 4. Hasil Uji secara Simultan (f)

ANOVA $^{a}$

\begin{tabular}{lll|l|l|l|l} 
Model & & Sum of Squares & $\mathrm{df}$ & Mean Square & F & Sig. \\
\hline 1 & Regression & 1.775 & 2 & .888 & 4.001 & $.030^{\mathrm{b}}$ \\
\cline { 2 - 7 } & Residual & 5.991 & 27 & .222 & & \\
\cline { 2 - 7 } & Total & 7.767 & 29 & & & \\
\hline
\end{tabular}

a. Dependent Variable: ROA

a. Predictors: (Constant), CAR, NIM

Sumber: Diolah oleh penulis dengan menggunakan SPSS versi 25 
Berdasarkan hasil nilai Fhitung $4.001>$ Ftabel 3.32 dengan tingkat signifikansi $0.030<0.05$. Maka peneliti dapat menyimpulkan bahwa terdapat pengaruh signifikan antara CAR dan NIM terhadap ROA secara silmutan. Dengan demikian Ha diterima.

\section{KESIMPULAN}

Peneliti dapat menyimpulkan bahwa Rasio Net Interest Margin serta Capital Adequancy Ratio berpengaruh secara signifikan terhadap tingkat pengembalian asset (Return On Asset) . Margin bunga bersih memiliki pengaruh yang signifikan dan berpengaruh positif terhadap tingkat pengembalian aset. Rasio kecukupan modal secara signifikan mempengaruhi tingkat pengembalian aset (Return On Asset) dan berbanding lurus dengan itu.

Dari kesimpulan di atas, para pemilik bisnis harus dapat dan mampu mengidentifikasi risiko yang mungkin terjadi dalam kegiatan bisnis. Dalam pengambilan keputusan / investasi, beberapa faktor bank seperti NIM dan CAR harus diperhatikan karena kedua faktor tersebut juga memiliki pengaruh yang cukup signifikan terhadap kinerja keuangan bank yang diukur dengan rasio profitabilitas yaitu return on asset.

Serta bagi peneliti selanjutnya diharapkan akan lebih baik meneliti variabel lain selain variabel ini untuk mendapatkan hasil yang lebih beragam contohnya Leverage untuk menggambarkan faktor-faktor yang mempengaruhi profitabilitas (ROA). Direkomendasikan untuk memperluas cakupan penelitian mengenai dampak NIM dan CAR terhadap profitabilitas Bank Nasional Indonesia (BNI) periode tahun 2013 hingga 2020.

\section{DAFTAR PUSTAKA}

Aakesa, A. (2006). Bank dan Lembaga Keuangan Bank. Jakarta: PT> Index Kelompok Gramedia.

Adiwarman, K. (2004). Bank Islam. Jakarta: PT Raja Grafindo.

Ayunigrum, A. P. (2011). Analisis Pengaruh CAR, NPL, BOPO, NIM dan LDR terhadap ROA.

Budisantoso, T., \& Triandaru, s. (2006). Bank dan Lembaga Keuangan Lain. Jakarta: Salemba Empat.

Dendawijaya, L. (2009). Manajemen Perbankan. Bogor: Ghalia Indonesia.

Ghazali, I. (2011). Aplikasi Analisis Multivariate dengan Program IBM SPSS 19 (edisi kelima). Semarang: Unversitas Diponogoro.

Ghozali. (2016). Aplikasi AnalisisMultivariate dengan Program SPSS. Cet . VIII. Semarang: Badan Penerbitan Universitas Dipanegoro.

Hanafi, M. (2012). Manajemen Risiko Edisi Kedua. Yogyakarta: UPP STIM YKPN .

Harsanti, C. D. (2016). Analisis Pengaruh Risiko Kredit, Risiko Pasar, Risiko Likuiditas, dan Risiko Operasional Terhadap Tingkat Pertumbuhan LabaBank Umum Di Indonesia. Publikasi Ilmiah Universitas Sebelas maret Surakarta.

Hasibuan. (2007). Dasar - Dasar Perbankan. Jakarta: PT. Bumi Aksara.

Jumingan. (2006). Analisis Laporan Keuangan. Jakarta: PT. Rajagrafindo.

Kasmir. (2014). Bank dan Lembaga keuangan Lainnya. Jakarta: Rajawali Pers. 
Mahardian. (2003). engelolaan Kredit Pada Bank Perkreditan Rakyat. jurnal Ekonomi \& Bisnis.No. 3 Jilid 8.

Putri, F. S. (2013). Pengaruh risiko kredit dan tingkat kecukupan modal terhadap tingkat profitabilitas pada perusahaan perbankanyang terdaftar di bursa efek indonesia.

Ramadhan, N. A. (2018). Pengaruh Risiko Kredit, Risiko Likuiditas Danrisiko Pasar Terhadap Profitabilitas Perusahaan Perbankan yang terdaftar Di Bursa Efek Indonesia (Bei)Periode 2013-2017.

Sugiyono. (2015). Metode Penelitian Kunatitatif, Kulitatif dan RED . Bandung: Alfabeta.

Ulber, S. (2009). Metode Penelitian Sosial. Jakarta: Refrika Aditama.

Varadigna, A. (2017). Pengaruh Risiko Valuta Asing dan Risiko Pasar Terhadap Profitabilitas(Studi pada Bank Devisa yang Terdaftar di BEI Periode 2013-2015).

Veithzal, R. (2010). Islamic Banking (sebuah teori,konsep dan Aplikasi). Jakarta: PT. Bumi Aksara.

Wisnu, M. (2005). Analisis Faktor - faktor yang mempengaruhi Kinerja Keuangan Bank Umum di Indonesia (Studi Kasus pada Bank umum dengan total asset kurang dari 1 Triliun). Jurnal Bisnis Strategi. 